\title{
White lupine yield under different sowing densities and row spacings
}

\author{
Antônio L. Santi ${ }^{1}$, Geomar M. Corassa ${ }^{2}$, Ronei Gaviraghi ${ }^{3}$, \\ Thomas N. Martin ${ }^{4}$, Mateus B. Bisognin ${ }^{3} \&$ Lisandra P. D. Flora ${ }^{5}$ \\ ${ }^{1}$ Universidade Federal de Santa Maria/Departamento de Ciências Agronômicas e Ambientais. Frederico Westphalen, RS. E-mail: santi_pratica@yahoo.com.br \\ ${ }^{2}$ Universidade Federal de Santa Maria/Programa de Pós-Graduação em Engenharia Agrícola. Santa Maria, RS. E-mail: geomarmateus@hotmail.com \\ (Corresponding author) \\ ${ }^{3}$ Universidade Federal de Santa Maria. Frederico Westphalen, RS. E-mail: roneigaviraghi@hotmail.com; mateusbisognin@hotmail.com \\ ${ }^{4}$ Universidade Federal de Santa Maria/Programa de Pós-Graduação em Agronomia/Departamento de Fitotecnia. Santa Maria, RS. E-mail: martin.ufsm@gmail.com \\ ${ }^{5}$ Instituto Federal Farroupilha. Frederico Westphalen, RS. E-mail: lisandra.dellaflora@iffarroupilha.edu.br
}

\section{Key words:}

Lupinus albus L.

management

fresh matter

dry matter

\begin{abstract}
A B S T R A C T
The study aimed to evaluate different sowing densities and row spacings on grain yield and biomass in the white lupine crop, cv. 'Comum'. The experimental design was a randomized block in a $4 \times 4$ factorial scheme, with four row spacings (20, 40, 60 and $80 \mathrm{~cm})$ and four sowing densities in the row $\left(10,15,20\right.$ and 25 plants $\left.\mathrm{m}^{-1}\right)$, with four replicates. The evaluated variables were: grain yield, hundred-grain weight, fresh and dry matter and the contents of nitrogen, phosphorus and potassium in the plant tissue. The highest grain yield was obtained with row spacing of $20 \mathrm{~cm}$, regardless of plant density. The density of 25 plants $\mathrm{m}^{-1}$ and row spacing of $20 \mathrm{~cm}$ increased the fresh and dry matter yield. The adjustment of plant density and row spacing did not affect the content of nitrogen, phosphorus and potassium in plant tissue.
\end{abstract}

\section{Palavras-chave:} Lupinus albus L. manejo massa verde massa seca

\section{Produtividade de tremoço branco submetido a diferentes densidades de semeadura e espaçamento entre fileiras}

\begin{abstract}
R E S U M O
Realizou-se este estudo com o objetivo de avaliar o uso de diferentes densidades de semeadura e espaçamentos entre fileiras sobre a produtividade de grãos e biomassa, na cultura do tremoço branco cultivar comum. O delineamento experimental foi o de blocos ao acaso, em esquema fatorial 4 x 4, com quatro espaçamentos entre fileiras $(20,40,60$ e 80 $\mathrm{cm})$ e quatro densidades na fileira de semeadura $\left(10,15,20\right.$ e 25 plantas $\left.\mathrm{m}^{-1}\right)$ com quatro repetições. As variáveis avaliadas foram: produtividade de grãos, massa de cem grãos, massa verde e seca da parte aérea e os teores de nitrogênio, fósforo e potássio no tecido vegetal. A maior produtividade de grãos foi obtida com espaçamento entre fileiras de 20 $\mathrm{cm}$, independente da densidade de plantas. A densidade de 25 plantas $\mathrm{m}^{-1}$ e o espaçamento entre fileiras de $20 \mathrm{~cm}$ aumentaram a produtividade de massa verde e seca. O ajuste da densidade de plantas e do espaçamento entre fileiras não alterou os teores de nitrogênio, fósforo e potássio no tecido vegetal.
\end{abstract}




\section{INTRODUCTION}

Lupinus albus L. (white lupine) has been pointed as an important alternative for the recovery of degraded soils (Rovedder \& Eltz, 2008; Rovedder et al., 2010) and as an option in the form of soil cover in crop rotation systems (Bevilacqua et al., 2008; Lázaro et al., 2013; Cargnelutti Filho et al., 2014). Characteristics such as the adaptation to soils of low fertility (Bevilacqua et al., 2008), high biomass production and high capacity of cycling of nutrients in the soil, especially nitrogen $(\mathrm{N})$, are present in the crop (Borkert et al., 2003; Bevilacqua et al., 2008; Ziech et al., 2015).

The utilization of white lupine in crop rotation plans is also able to increase the yield of the subsequent crops, such as maize (Gonçalves et al., 2000; Lázaro et al., 2013), and to promote the protection and structuration of the soil (Rovedder et al., 2010; Teixeira et al., 2010; Cremonez et al., 2013). However, despite having several benefits, the utilization of white lupine in agricultural systems is small, especially due to the lack of information on crop management.

Testing the sowing densities and row spacings for Lupinus albescens Hook. \& Arn. in a dystrophic Quartzarenic Neosol (EMBRAPA, 2006) under degradation (arenization), Rovedder et al. (2010) observed that the spacing of $17 \mathrm{~cm}$ was the most efficient for biomass yield and that the number of seeds per linear meter did not show significant effect. However, this information is still incipient for white lupine in areas of agricultural production. Greater subsidies referring to the efficient crop management could contribute to its adoption in large scale and facilitate its insertion in crop rotation systems. The knowledge on the best adjustment for plant density and row spacing could potentiate crop yield.

Thus, this study aimed to evaluate grain and biomass yields of white lupine as a function of different sowing densities and row spacings.

\section{Material ANd Methods}

The experiments were conducted in the agricultural year of 2012, in two sites, in the municipalities of Frederico Westphalen and Seberi, in Rio Grande do Sul, Brazil. The first one is located at the experimental area of the Federal University of Santa Maria, Campus of Frederico Westphalen, RS (27 23' 23.65” S; $53^{\circ} 25^{\prime} 44.02^{\prime \prime} \mathrm{W} ; 480 \mathrm{~m}$ ), while the second one is located in a rural property situated in the municipality of Seberi-RS $\left(27^{\circ}\right.$ $36^{\prime} 21.24^{\prime \prime}$ S; $53^{\circ} 22^{\prime} 36^{\prime \prime} \mathrm{W} ; 548 \mathrm{~m}$ ). The local climate, according to the classification of Maluf (2000), is subtropical with humid spring (ST HS), mean annual temperature of $18.1^{\circ} \mathrm{C}$ and mean annual rainfall of $1,919 \mathrm{~mm}$. The mean temperature and cumulative rainfall during the experimental period were 16.6 ${ }^{\circ} \mathrm{C}$ and $761 \mathrm{~mm}$, respectively, for Frederico Westphalen, and $16.6^{\circ} \mathrm{C}$ and $782 \mathrm{~mm}$ for Seberi.

The soil of both sites is classified as dystrophic Red Latosol, with clayey texture (EMBRAPA, 2006), and had been conducted under consolidated no-tillage system (NTS). Soil sampling in the layer of $0.00-0.10 \mathrm{~m}$ evidenced the following physicochemical characteristics: $74 \%$ of clay; base saturation of $58 \%$; $\mathrm{pH}$ in $\mathrm{H}_{2} \mathrm{O}$ of $5.8 ; 9.3 \mathrm{mg} \mathrm{dm}^{-3}$ of phosphorus (P)
(Mehlich-1); $238 \mathrm{mg} \mathrm{dm}^{-3}$ of potassium (K); 3.2\% of organic matter $(\mathrm{OM})$ and $0.4 \mathrm{mg} \mathrm{dm}^{-3}$ of aluminum (Al) for Frederico Westphalen and $65 \%$ of clay; base saturation of $68 \%$; $\mathrm{pH}$ in $\mathrm{H}_{2} \mathrm{O}$ of $5.6 ; 14.33 \mathrm{mg} \mathrm{dm}^{-3}$ of $\mathrm{P}$ (Mehlich-1); $165 \mathrm{mg} \mathrm{dm}^{-3}$ of $\mathrm{K} ; 3.2 \%$ of $\mathrm{OM}$ and $0.8 \mathrm{mg} \mathrm{dm}^{-3}$ of $\mathrm{Al}$ for Seberi.

The experiments were installed after the harvest of the soybean crop (Glycine max L.) in a randomized block design and the treatments were distributed in a $4 \times 4$ factorial scheme, with four row spacings $(20,40,60$ and $80 \mathrm{~cm})$ and four plant densities in the sowing row $(10,15,20$ and 25 plants per meter), with four replicates. The experimental units had a total area of $12 \mathrm{~m}^{2}$.

The white lupine, cv. 'Comum', was manually sown on June 14 and 28, 2012, in Frederico Westphalen and Seberi, respectively, at a depth of $5 \mathrm{~cm}$. After plant emergence, the populations were adjusted in the sowing rows through thinning, in order to guarantee the desired final population. Fertilization was performed using $250 \mathrm{~kg} \mathrm{ha}^{-1}$ of NPK fertilizer (05.20.20), applied broadcast before sowing, according to the technical recommendations of the Manual of Fertilization and Liming for the States of Rio Grande do Sul and Santa Catarina (CQFS-RS/SC, 2004), for an expected grain yield of $2000 \mathrm{~kg}$ $\mathrm{ha}^{-1}$. Weeds were controlled through weedings and manual uprooting.

The analyzed variables were: shoot fresh matter yield (FM, $\mathrm{kg} \mathrm{ha}^{-1}$ ), shoot dry matter yield (DM, $\mathrm{kg} \mathrm{ha}^{-1}$ ), grain yield (GY, $\mathrm{kg} \mathrm{ha}^{-1}$ ), hundred-grain weight (HGW, g) and the contents of nitrogen $\left(\mathrm{N}, \mathrm{g} \mathrm{kg}^{-1}\right)$, phosphorus $\left(\mathrm{P}, \mathrm{g} \mathrm{kg}^{-1}\right)$ and potassium $(\mathrm{K}$, $\left.\mathrm{g} \mathrm{kg}^{-1}\right)$ in the plant tissue. Plant shoots were collected along a 2-m-long row, in each experimental unit, for the determination of FM and DM, on September 1, 2012 (Frederico Westphalen) and on September 8, 2012 (Seberi), during the flowering of the crop (79 and 72 days after sowing - DAS, respectively). The plants were weighed - for the determination of FM - and then dried in an oven at $65{ }^{\circ} \mathrm{C}$ until constant weight, for the determination of DM. From the samples, FM and DM yields were converted to $\mathrm{kg} \mathrm{ha}^{-1}$, considering the row spacings of each treatment.

GY was determined through the manual harvest of the plants in the central rows of the experimental units, disregarding $0.5 \mathrm{~m}$ on each side. Harvest was performed on October 22 and 31, 2012, in Frederico Westphalen (130 DAS) and Seberi (125 DAS), respectively. The collected plants were later threshed and GY was corrected to $13 \%$ of moisture. The contents of $\mathrm{N}, \mathrm{P}$ and $\mathrm{K}$ in the plant tissue were determined using samples of plants collected during the flowering of the crop, which were dried and ground in 1-mm-mesh sieve. The analyses were performed using the methodology proposed by Tedesco et al. (1995).

The data were subjected to analysis of variance using the program Genes (Cruz, 2006), initially performing an individual analysis for each site. Subsequently, the mean square of the experimental error (MSE) was evaluated in order to investigate the possibility of a joint analysis, which was performed when the relationship between the MSEs was lower than four (Box, 1954). When significance was observed, complementary analyses were applied and the data were compared through the polynomial regression analysis $(\mathrm{p} \leq 0.05)$. 


\section{Results AND Discussion}

According to the analyses of variance and MSE, for all evaluated variables, the relationship between the MSEs (upper and lower) was lower than four, indicating homoscedasticity (Box, 1954). Hence, a joint analysis used and the results were considered for both sites (Box, 1954) (Table 1).

The contents of N, P and $\mathrm{K}$ in the plant tissue did not differ for any of the studied treatments, indicating that plant density (PD) and row spacing (RS) do not influence the dynamics of absorption of these nutrients by white lupine plants. The observed mean contents of N, P and $\mathrm{K}$ were $31.60,2.70$ and $31.90 \mathrm{~g} \mathrm{~kg}^{-1}$, respectively, with coefficients of variation of $15.67 \%(\mathrm{~N}), 18.95 \%(\mathrm{P})$ and $37.27 \%(\mathrm{~K})$ (Table 1). These results are similar to those obtained by Ziech et al. (2015), who reported $\mathrm{N}$ cycling of 27 to $31 \mathrm{~g} \mathrm{~kg}^{-1}$ and reinforced that the white lupine is able to cycle satisfactory amounts of $\mathrm{N}$ (Borkert et al., 2003).

There was no significant interaction between RS and PD for GY (Table 1). The PD in the row also did not influence GY, which suggests that, when white lupine cultivation aims at GY, the PD of 10 plants can be used without losses, being an alternative for the reduction of production costs (acquisition of seeds).

RS showed significant effect on GY (Table 1). The results evidence a quadratic fit for GY in the different $R S\left(R^{2}=0.88\right)$. The highest GY was observed at the RS of $20 \mathrm{~cm}$ with $2,335 \mathrm{~kg}$ $\mathrm{ha}^{-1}$, while the RS of $80 \mathrm{~cm}$ resulted in a GY of $1,241 \mathrm{~kg} \mathrm{ha}^{-1}$ (Figure 1A).

These results may be related to the lower intraspecific competition between plants in the row (Rambo et al., 2003), promoted by the reduction in RS. Rovedder et al. (2010), in studies with Lupinus albescens Hook. \& Arn. in southeast Rio Grande do Sul (Pampa biome), observed that the reduction of RS resulted in lower number of grains per plant. However, these authors highlight that this result cannot be considered as an isolated parameter for GY, since it does not contemplate the compensatory effect of other components. The lower number of grains per plant is possibly counterbalanced by the higher individual weight of grains, which results in an increase in GY. The effect of the reduction in RS on the increase of GY has also been observed in other fabaceae plants cultivated in NTS, such as soybean (Glycine max L.) (Tourino et al., 2002; Rambo et al., 2003) and common bean (Phaseolus vulgaris L.) (Morais et al., 2001).

The HGW was influenced by PD in the row (Table 1 ) and showed a linear response $\left(\mathrm{R}^{2}=0.71\right)$ (Figure 1B). The lowest
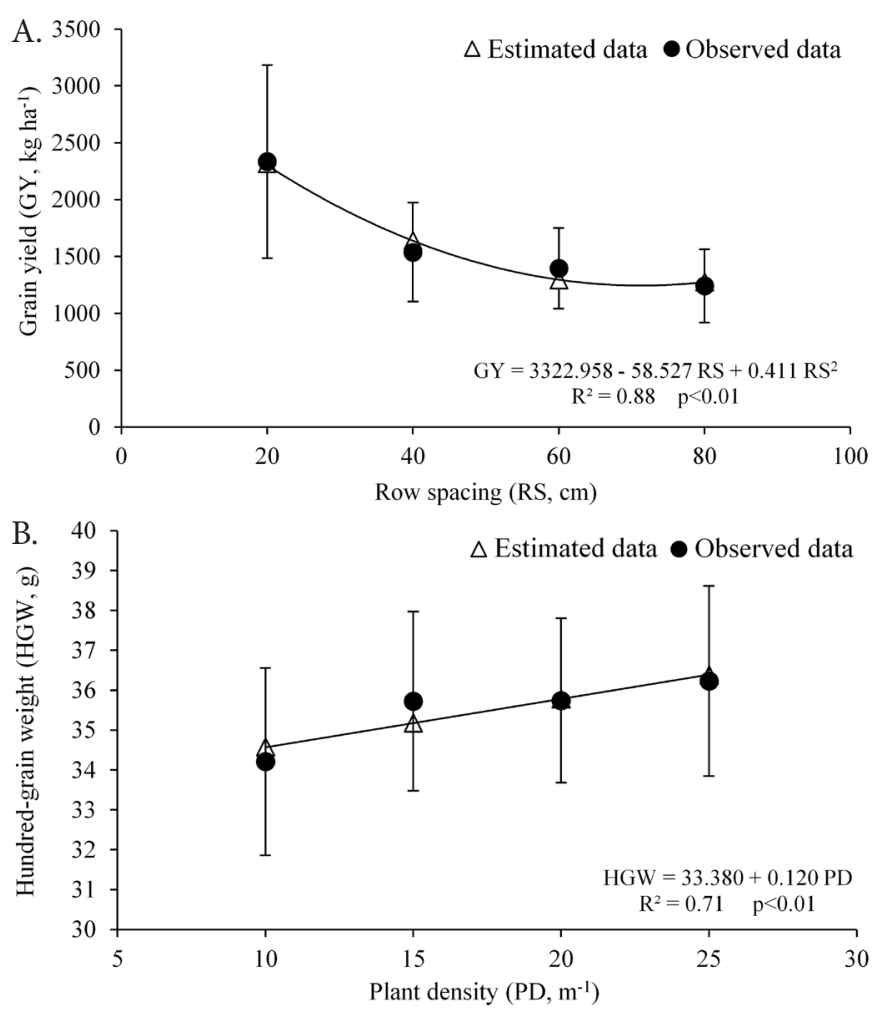

Vertical lines indicate the standard deviation

Figure 1. Grain yield of white lupine for the different row spacings (A) and hundred-grain weight for the different plant densities (B)

values of HGW (34.21 g) were obtained with a PD of 10 plants in the row, while the increase of PD to 25 plants resulted in an increase of HGW to $36.23 \mathrm{~g}$, which represents an increment of $0.12 \mathrm{~g}$ for each additional plant in the sowing row (Figure 1B). These results may indicate that the increase in PD along the row may be reducing the number of grains per plant and favoring the individual weight of grains. Thus, the HGW may have its effect minimized by the reduction in the number of grains per plant (Rovedder et al., 2010). These results reinforce the fact that PD did not cause significant effect on GY in the present study.

The FM showed significant interaction between RS and PD (Table 1). The response surface analysis evidenced that the highest FM yield is obtained at RS of $20 \mathrm{~cm}$ associated with a PD of 25 plants $\left(51,739.76 \mathrm{~kg} \mathrm{ha}^{-1}\right)$ (Figure 2).

Thus, the FM is favored by the reduction in RS when higher PD is used. The reduction in RS, however, has greater contribution to the increase in FM in relation to the increase of PD (Figure 2). These results reveal that, when the production

Table 1. Summary of the analysis of variance considering both experimental sites for the variables grain yield (GY), hundred-grain weight $(\mathrm{HGW})$, fresh $(\mathrm{FM})$ and dry matter $(\mathrm{DM})$ and contents of nitrogen $(\mathrm{N})$, phosphorus $(\mathrm{P})$ and potassium $(K)$ in the plant tissue

\begin{tabular}{|c|c|c|c|c|c|c|c|}
\hline \multirow{2}{*}{$\begin{array}{c}\text { Source } \\
\text { of variation }\end{array}$} & GY & HGW & FM & DM & $\mathbf{N}$ & $\mathbf{P}$ & K \\
\hline & \multicolumn{7}{|c|}{$\operatorname{Pr}>F$} \\
\hline RS & $0.000^{\star *}$ & $0.286^{\mathrm{ns}}$ & $0.000^{* *}$ & $0.000^{* *}$ & $0.310^{\text {ns }}$ & 0.524 ns & 0.928 ns \\
\hline PD & $0.702^{\mathrm{ns}}$ & $0.004^{\star *}$ & 0.000 ** & $0.014^{*}$ & $0.780^{\mathrm{ns}}$ & $0.310^{\mathrm{ns}}$ & $0.937^{\mathrm{ns}}$ \\
\hline $\mathrm{RS} \times \mathrm{PD}$ & $0.183^{\text {ns }}$ & 0.749 ns & $0.019^{*}$ & 0.617 ns & $0.421^{\text {ns }}$ & $0.942^{\text {ns }}$ & 0.998 ns \\
\hline Mean & 1636.95 & 35.47 & 31073.83 & 2981.78 & 31.60 & 2.70 & 31.90 \\
\hline CV (\%) & 32.49 & 6.45 & 19.47 & 28.76 & 15.67 & 18.95 & 37.27 \\
\hline
\end{tabular}

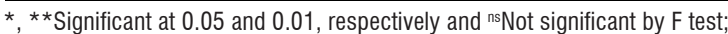

RS - Row spacing; PD - Plant density; CV - Coefficient of variation 


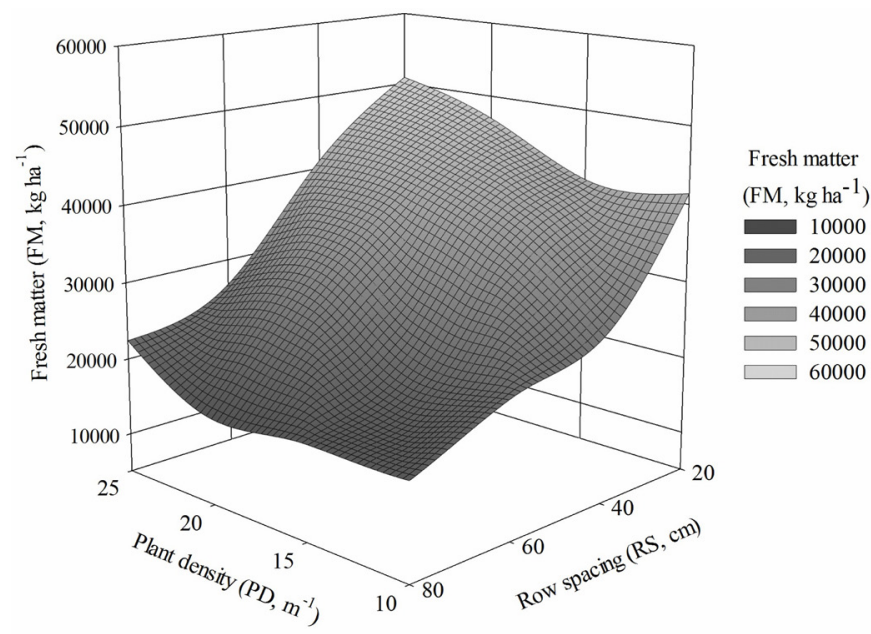

$\mathrm{FM}=39028.823+1000.004 \mathrm{PD}+0.749 \mathrm{PD}^{2}-450.704 \mathrm{RS}+1.442 \mathrm{RS}^{2}-8.640 \mathrm{PD} \mathrm{RS}$ $\mathrm{R}^{2}=0.65 \quad \mathrm{p}<0.01$

Figure 2. Response surface of fresh matter yield of white lupine as a function of the row spacing and plant density

aims at FM yield, the use of lower RS must be recommended and, whenever possible, associated with the highest PD. The reduction in RS must also be recommended when a higher soil cover rate is desired, since white lupine has an upright tree growth habit (Ziech et al., 2015).

Plant DM was influenced by RS (Figure 3A). According to the quadratic fit obtained for the regression analysis $\left(\mathrm{R}^{2}=\right.$ 0.97), DM decreased as RS increased.

The highest DM yield was obtained with RS of $20 \mathrm{~cm}$, while the lowest was obtained with RS of $80 \mathrm{~cm}$ (Figure 3A). The reduction in RS from 80 to $20 \mathrm{~cm}$ resulted in a DM increment of about $160 \%$ and would be representing a cycling of 145,12
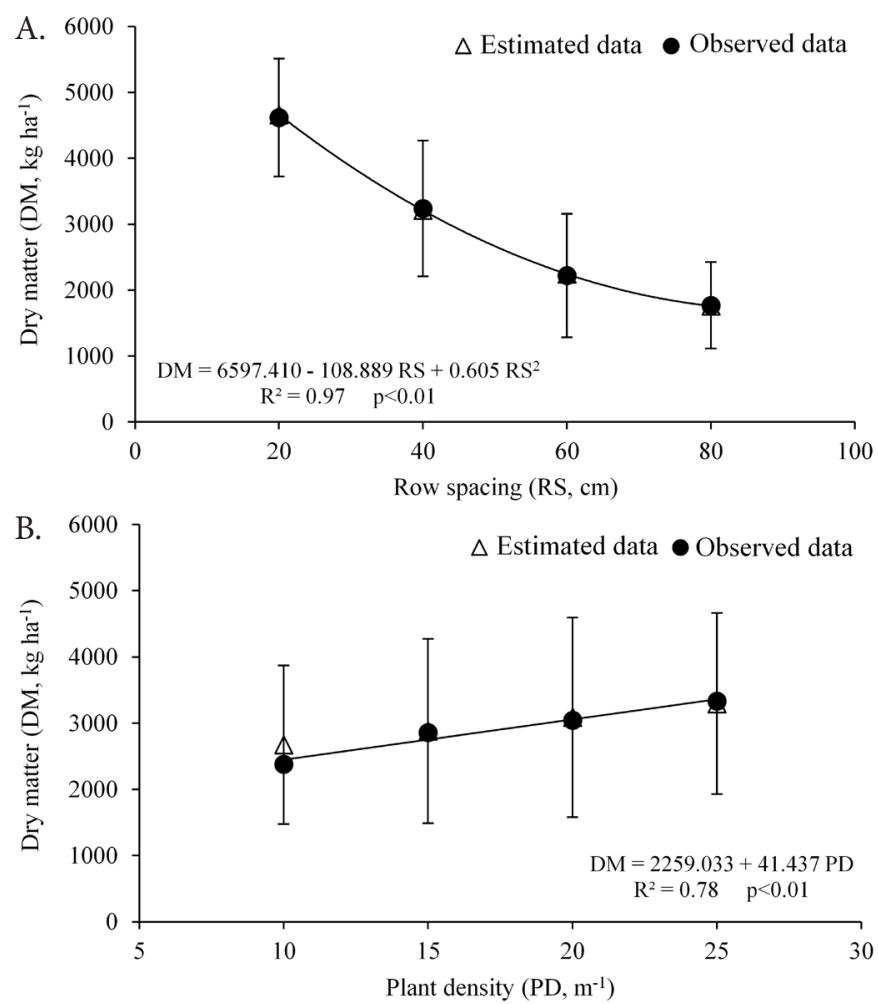

Vertical lines indicate the standard deviation

Figure 3. Dry matter yield of white lupine for the different row spacings (A) and different plant densities (B) and $147 \mathrm{~kg} \mathrm{ha}^{-1}$ of $\mathrm{N}, \mathrm{P}$ and $\mathrm{K}$, respectively, based on the mean contents obtained for these nutrients. Studying cover plants for soil protection, Ziech et al. (2015) observed a DM yield of 3,000 $\mathrm{kg} \mathrm{ha}^{-1}$ in the white lupine crop for RS of $50 \mathrm{~cm}$. These results are in agreement with those obtained in the present study.

The benefits of using lower RS are possibly related to the increase in the efficiency of use of environmental resources (light, water and nutrients), due to the better distribution of the plants in the area (Tourino et al., 2002; Rambo et al., 2003). These results are similar to those reported by Rovedder et al. (2010), in which the RS of $17 \mathrm{~cm}$ also favored shoot biomass. Because of this, these authors point out that the use of lower RS can be an alternative when higher biomass yield is desired. Reduced RS can also promote higher protection of the soil, since it is rapidly covered, due to the greater proximity between plants (Rovedder et al., 2010; Ziech et al., 2015). In addition, the production of greater DM volume promotes a thicker cover on the soil, contributing to the reduction of water erosion and, consequently, leading to smaller soil losses (Cardoso et al., 2012). The greater soil cover also favors the control of weeds and improves soil physical, chemical and biological characteristics (Menezes et al., 2009; Leite et al., 2010; Carvalho et al., 2013), which would be desirable effects for the use of white lupine as an alternative in crop rotation systems (Rovedder et al., 2010).

The highest DM was obtained with the use of PD of 25 plants in the sowing row (Figure $3 \mathrm{~B}$ ). The data obtained for the linear fit $\left(\mathrm{R}^{2}=0.78\right)$ reveal a DM increment of $953 \mathrm{~kg} \mathrm{ha}^{-1}$, in the comparison between the PD of 25 and the PD of 10 (Figure $3 \mathrm{~B})$. The results suggest that the increment in $\mathrm{PD}$ in the sowing row is a factor that must also be recommended when higher DM yield is desired in the white lupine crop. These results differ from those obtained by Rovedder et al. (2010), who did not find significant difference working with 4, 8, 12, 16 and 20 plants per linear meter; however, the authors agree that the use of higher PD could be an advantageous alternative with respect to soil protection.

High biomass production and efficient soil cover are desirable characteristics in cover plants (Carvalho et al., 2013; Cardoso et al., 2012) and, in the case of white lupine, these are directly related to the adjustment of its RS and PD. Therefore, the understanding about management practices that interfere with the crop becomes fundamental to maximizing yield (Ortiz et al., 2015). The adjustments of RS and PD are factors that can allow the adoption of white lupine in crop rotation systems, since they are able to increase the productive potential.

\section{Conclusions}

1. Plant density did not interfere with grain yield, which was higher when a row spacing of $20 \mathrm{~cm}$ was used.

2. The use of 25 plants per linear meter associated with a row spacing of $20 \mathrm{~cm}$ is more efficient for fresh and dry matter yield.

3. The adjustment of plant density and row spacing must be performed according to the objective of the production: grains or biomass, because it does not alter the contents of nitrogen, phosphorus and potassium in the plant tissue. 


\section{Literature Cited}

Bevilacqua, G. A. P.; Antunes, I. F.; Zuchi, J.; Marques, R. L. L. Indicações técnicas para produção de sementes de plantas recuperadoras do solo para a agricultura familiar. Pelotas: Embrapa Clima Temperado, 2008. 43p. Documentos, 227

Borkert, C. M.; Gaudêncio, C. de A.; Pereira, J. E.; Pereira, L. R.; Oliveira Junior, A. de. Nutrientes minerais da biomassa da parte aérea em culturas de cobertura de solo. Pesquisa Agropecuária Brasileira, v.38, p.143-153, 2003. http://dx.doi.org/10.1590/S0100204X2003000100019

Box, G. E. P. Some theorems on quadratic forms applied in the study of analysis of variance problems: I. Effect of inequality of variance in the one-way classification. Annals of Mathematical Statistics, v.25, p.290-302, 1954. http://dx.doi.org/10.1214/aoms/1177728786

Cardoso, D. P.; Silva, M. L. N.; Carvalho, G. J.; Freitas, D. A. F.; Avanzi, J. C. Plantas de cobertura no controle das perdas de solo, água e nutrientes por erosão hídrica. Revista Brasileira de Engenharia Agrícola e Ambiental, v.16, p.632-638, 2012. http://dx.doi. org/10.1590/S1415-43662012000600007

Cargnelutti Filho, A.; Toebe, M.; Burin, C.; Alves, B. M.; Facco, G.; Casarotto, G. Relações lineares entre caracteres de nabo forrageiro e de tremoço branco. Ciência Rural, v.44, p.18-24, 2014. http:// dx.doi.org/10.1590/S0103-84782014000100004

Carvalho, W. P. de; Carvalho, G. J. de; Abbarde Neto, D. O.; Teixeira, L. G. V. Desempenho agronômico de plantas de cobertura usadas na proteção do solo no período de pousio. Pesquisa Agropecuária Brasileira, v.48, p.157-166, 2013. http://dx.doi. org/10.1590/S0100-204X2013000200005

CQFS-RS/SC - Comissão de Química e Fertilidade do Solo. Manual de adubação e calagem para os Estados do Rio Grande do Sul e de Santa Catarina. 10.ed. Porto Alegre: Sociedade Brasileira de Ciência do Solo - Núcleo Regional Sul/Universidade Federal do Rio Grande do Sul, 2004. 400p.

Cremonez, P. A.; Feroldi, M.; Feiden, A.; Rossi, E. de; Nadaleti, W. C.; Antonelli, J. Tremoço: Manejo e aplicações. Acta Iguazu, v.2, Suplemento, p.98-108, 2013.

Cruz, C. D. Programa Genes: Estatística experimental e matrizes. Viçosa: UFV, 2006. 285p.

EMBRAPA - Empresa Brasileira de Pesquisa Agropecuária. Sistema brasileiro de classificação de solos. 2.ed. Rio de Janeiro: Embrapa Solos; Brasília: Sistema de Produção de Informação, 2006. 306p.

Gonçalves, C. N.; Ceretta, C. A.; Basso, C. J. Sucessão de culturas com plantas de cobertura e milho em plantio direto e sua influência sobre o nitrogênio no solo. Revista Brasileira de Ciência do Solo, v.24, p.153-159, 2000. http://dx.doi.org/10.1590/S010006832000000100017

Lázaro, R. L; Costa, A. T. da; Silva, K. de F. da; Sarto, M. V. M.; Duarte Júnior, J. B. Produtividade de milho cultivado em sucessão à adubação verde. Pesquisa Agropecuária Tropical, v.43, p.10-17, 2013. http://dx.doi.org/10.1590/S1983-40632013000100008
Leite, L. F. C.; Freitas, R. C. A.; Sagrilo, S.; Galvão, S. R. S. Decomposição e liberação de nutrientes de resíduos vegetais depositados sobre Latossolo Amarelo no cerrado Maranhense. Revista Ciência Agronômica, v.41, p.29-35, 2010.

Maluf, J. R. T. Nova classificação climática do Estado do Rio Grande do Sul. Revista Brasileira de Agrometeorologia, v.8, p.141-150, 2000.

Menezes, L. A. S.; Leandro, W. M.; Oliveira Júnior, J. P.; Ferreira, A. C. B.; Santana, J. G.; Barros, R. G. Produção de fitomassa de diferentes espécies, isoladas e consorciadas, com potencial de utilização para cobertura do solo. Bioscience Journal, v.25, p.712, 2009.

Morais, L. K.; Carbonell, S. A. M.; Pinheiro, J. B.; Fonseca, N. da S.; Brasil, E. M. Avaliação de cultivares de feijoeiro, Phaseolus vulgaris L., sob diferentes espaçamentos. Acta Scientiarum, v.23, p.1199-1203, 2001.

Ortiz, S.; Martin, T. N.; Brum, M. da S.; Nunes, N. V.; Stecca, J. D. L.; Ludwig, R. L. Densidade de semeadura de duas espécies de ervilhaca sobre caracteres agronômicos e composição bromatológica. Ciência Rural, v.45, p.245-251, 2015. http:// dx.doi.org/10.1590/0103-8478cr20140291

Rambo, L.; Costa, J. A.; Pires, J. L. F.; Parcianello, G.; Ferreira, F. G. Rendimento de grãos da soja em função do arranjo de plantas. Ciência Rural, v.33, p.405-411, 2003. http://dx.doi.org/10.1590/ S0103-84782003000300003

Rovedder, A. P. M.; Eltz, F. L. F. Revegetação com plantas de cobertura em solos arenizados sob erosão eólica no Rio Grande do Sul. Revista Brasileira de Ciência do Solo, v.32, p.315-321, 2008.

Rovedder, A. P. M.; Eltz, F. L. F.; Drescher, M. S.; Dorneles, F. de O.; Schenato, R. B. Espaçamento entre linhas e densidade de semeadura em revegetação com espécie de tremoço visando à recuperação de solo degradado. Ciência Rural, v.40, p.1955-1960, 2010. http://dx.doi.org/10.1590/S0103-84782010005000135

Tedesco, M. J.; Gianello, C.; Bissani, C. A.; Bohnen, H.; Volkweiss, S. J. Análises de solo, plantas e outros materiais. 2.ed. Porto Alegre: UFRGS, 1995. 174p.

Teixeira, G.; Katrochan, K.; Varennes, A. de; Martins, J. N.; Stuetze, H. O uso da semente de tremoço como fertilizante azotado. Revista de Ciências Agrárias, v.33, p.118-133, 2010.

Tourino, M. C. C.; Rezende, P. M. de; Salvador, N. Espaçamento, densidade e uniformidade de semeadura na produtividade e características agronômicas da soja. Pesquisa Agropecuária Brasileira, v.37, p.1071-1077, 2002. http://dx.doi.org/10.1590/ S0100-204X2002000800004

Ziech, A. R. D.; Conceição, P. C.; Luchese, A. V.; Balin, N. M.; Candiotto, G.; Garmus, T. G. Proteção do solo por plantas de cobertura de ciclo hibernal na região Sul do Brasil. Pesquisa Agropecuária Brasileira, v.50, p.374-382, 2015. http://dx.doi. org/10.1590/S0100-204X2015000500004 